\title{
Pelatihan Standar Penanganan Pangan Rendang di Sentra Produksi Randang
}

\author{
Reinny Patrisina, Prima Fithri, Lusi Susanti, Hilma Raimona Zadry, Difana Meilani, \\ Eri Wirdianto, Jonrinaldi Jonrinaldi, Desto Jumeno, Asmuliardi Muluk, Alexie \\ Herryandie, Feri Afrinaldi, Henmaidi Henmaidi, Alfadhlani Alfadhlani, Insannul \\ Kamil, Dicky Fatrias, Taufik Taufik, Wisnel Wisnel, Alizar Hasan, Rika Ampuh \\ Hadiguna, Ahmad Syafruddin, Nilda Tri Putri, Elita Amrina, Ikhwan Arief, Afri Adnan \\ Fakultas Teknik, Universitas Andalas, Kampus Limau Manis, Padang, 25163. Indonesia \\ E-mail: primafithri@eng.unand.ac.id
}

Keywords: products, food, Good Manufacturing Practices (GMP) standardization

Kata Kunci: produk, pangan, Good Manufacturing Practices (GMP), standardisation

\begin{abstract}
Nowadays, consumers are getting smarter in choosing products, including food products. Food safety is an important thing that must be considered by the food industry. Unsafe food production can only be done because of food, product needs, lengthy legal process, but can also damage the community. Customer needs demand certainty from the food provided in a way that meets food safety standards, from the garden to the table. To fulfill this reason, all parties involved in the food production process must know and understand well matters related to food procurement standards for the products produced. Rendang is one of the traditional foods of West Sumatra that has begun worldwide. This requires the need to produce rendang with food safety standards is very important. Based on this, within the framework of the Community Service Department of Industrial Engineering UNAND conducts training / technical guidance related to the rendang food procurement standards with training on Good Manufacturing Practices (GMP). This activity was expected to help Small and Medium Enterprises to get business standardization.
\end{abstract}

\footnotetext{
ABSTRAK

Saat ini, konsumen sudah semakin cerdas dalam memilih produk, termasuk produk pangan. Keamanan pangan menjadi hal penting yang harus diperhatikan oleh industri pangan. Produksi makanan yang tidak aman tidak hanya dapat mengakibatkan keracunan makanan, penarikan produk, proses hukum yang panjang, tapi juga dapat merusak reputasi publik. Persyaratan pelanggan menuntut adanya kepastian bahwa makanan diproses dengan cara yang memenuhi standar keamanan pangan, mulai dari kebun sampai ke meja. Untuk memenuhi hal tersebut maka semua pihak yang terlibat dalam proses produksi pangan harus memiliki pengetahuan dan memahami dengan baik hal terkait standar penanganan pangan untuk produk yang diproduksi. Rendang merupakan salah satu makanan tradisional Sumatera Barat yang sudah mulai mendunia. Hal ini mengakibatkan kebutuhan untuk memproduksi rendang dengan standar keamanan pangan menjadi suatu hal yang sangat penting. Berdasarkan hal tersebut, maka dalam rangka Pengabdian Masyarakat Jurusan Teknik Industri UNAND melakukan pelatihan/bimbingan teknis terkait standar penanganan pangan rendang dengan melatih tentang Good Manufacturing Practices (GMP). Kegiatan ini diharapkan dapat membantu IKM untuk mendapatkan standarisasi usaha.
} 


\section{PENDAHULUAN}

Sumatera Barat merupakan salah satu provinsi di Indonesia yang terkenal akan kekayaan kulinernya. Kuliner seperti makanan khas dari daerah Minangkabau ini sudah terkenal tidak hanya secara nasional namun juga internasional. Kekayaan kuliner Sumatera Barat ini merupakan salah satu daya tarik bagi para wisatawan untuk datang ke Sumatera Barat.

Saat ini, konsumen sudah semakin cerdas dalam memilih produk, termasuk produk pangan. Keamanan pangan menjadi hal penting yang harus diperhatikan oleh industri pangan. UU No 8 Tahun 1999 tentang Perlindungan Konsumen, Bab III Pasal 4 menyatakan bahwa Hak konsumen adalah hak atas kenyamanan, keamanan, dan keselamatan dalam mengkonsumsi barang dan atau jasa. Dalam hal ini masyarakat perlu dilindungi kesehatan dan keselamatannya terhadap produksi dan peredaran makanan yang tidak memenuhi persyaratan tersebut. Setiap orang yang bertanggung jawab dalam penyelenggaraan kegiatan atau proses produksi, penyimpanan, pengangkutan, dan atau peredaran pangan wajib memenuhi persyaratan sanitasi, keamanan, dan atau keselamatan manusia (UU No 7 Tahun 1996 tentang Pangan, Bab II Pasal 7 ayat a).

Produksi makanan yang tidak aman tidak hanya dapat mengakibatkan keracunan makanan, penarikan produk, proses hukum yang panjang, tapi juga dapat merusak reputasi publik. Oleh karena itu, Industri Kecil dan Menengah (IKM) Pangan harus memenuhi syarat-syarat keamanan pangan bagi konsumennya. Pemerintah Provinsi Sumatera Barat sejak tahun 2018 telah mulai menggodok Peraturan Daerah (Perda) mengenai keamanan dan ketahanan pangan. Dengan demikian setiap pelaku usaha dalam sektor ini harus memiliki kemampuan untuk memenuhi persyaratan keamanan pangan tersebut.

Persyaratan keamanan pangan menuntut adanya kepastian bahwa makanan diproses dengan cara yang memenuhi standar keamanan pangan, mulai dari kebun sampai ke meja. Untuk memenuhi hal tersebut maka semua pihak yang terlibat dalam proses produksi pangan harus memiliki pengetahuan dan memahami dengan baik hal terkait standar penanganan pangan untuk produk yang diproduksi. Rendang merupakan salah satu makanan tradisional Sumatera Barat yang sudah mulai mendunia dan menurut CNN menjadi makanan terenak di dunia. Hal ini mengakibatkan kebutuhan untuk memproduksi rendang dengan standar keamanan pangan menjadi suatu hal yang sangat penting.

Masalah yang dihadapi industri pangan pada umumnya adalah masalah ketersediaan, mutu dan aspek legalitas pangan. Masalah mutu terkait masih rendahnya kualitas produk pangan ditinjau banyaknya kasus keracunan makanan. Berdasarkan data BPOM Sumatera Barat tahun 2016, sebanyak 14,9 persen dari sampel pangan tercatat tidak memenuhi syarat. Untuk menghasilkan makanan yang bermutu maka perlu dilakukan berbagai bentuk pembinaan kepada dunia usaha termasuk IKM pangan.

Berdasarkan analisis situasi yang dilakukan, maka dalam rangka Pengabdian Masyarakat Jurusan Teknik Industri UNAND melakukan pelatihan/bimbingan teknis terkait standar penanganan pangan rendang di sentra produksi randang.

Berdasarkan uraian yang telah dijelaskan di atas, maka perumusan masalah pada kegiatan ini adalah bagaimana bentuk Pelatihan Standar Penanganan Pangan Rendang di Sentra Produksi Randang dalam upaya meningkatkan kemampuan peserta untuk memberikan jaminan keamanan pangan bagi konsumen dan memenuhi persyaratan berbagai perizinan maupun sertifikasi. Salah satu kegiatan yang dilakukan adalah melakukan bimbingan dan pelatihan tentang Good Manufacturing Practices (GMP). GMP sangat diperlukan untuk semua dunia usaha (Adinegoro, 2016; Rudiyanto, 2016; Yudhastuti, 2014)

Adapun tujuan kegiatan ini adalah: 1). Mensosialisasikan pentingnya pemenuhan standar keamanan pangan. 2). Memberikan pemahaman kepada penjamah makanan dari IKM pengolahan produk rendang mulai dari persiapan, pemasakan, hingga pengemasan sesuai dengan standar yang telah ditetapkan dan produk yang dihasilkan sesuai dengan standar mutu yang diharapkan. 
Mitra yang dituju untuk kegiatan tersebut adalah IKM produsen rendang Koperasi wanita IKABOGA dan seluruh karyawan rendang Subana-bana Randang yang melakukan semua proses produksi, terdiri dari SDM bagian persiapan, bagian produksi, dan bagian pengemasan.

Kegiatan ini diharapkan bermanfaat bagi peserta pelatihan untuk meningkatkan kemampuan mereka dalam memenuhi persyaratan keamanan pangan. Penerapan materi pelatihan ini oleh peserta diharapkan mempermudah mereka dalam perizinan dan sertifikasi industri pangan. Dalam jangka panjang diharapkan akan membantu mereka dalam meningkatkan kepuasan konsumennya yang akan berdampak positif terhadap perluasan pasar, penguatan dalam persaingan, dan keberlanjutan bisnis setiap IKM peserta.

\section{METODE}

Kegiatan Pelatihan Standar Penanganan Pangan Rendang di Sentra Produksi Randang ini dilakukan pada tanggal 11 Maret 2019, bertempat di Sentra Produksi Randang Padang Koperasi Wanita IKABOGA, Pasar Raya Padang Fase III lt. 3, Padang. Pada kegiatan ini, tim pengabdian memberikan materi tentang standar penanganan produk pangan dan selanjutnya dilakukan pengukuran terhadap pemahaman peserta terkait standar penanganan pangan, khususnya Rendang.

Tabel 1. Jadwal dan bentuk kegiatan pengabdian kepada masyarakat.

\begin{tabular}{|c|l|}
\hline Jadwal & \multicolumn{1}{|c|}{ Acara } \\
\hline $10.00-10.15$ & Pembukaan \\
\hline $10.15-12.30$ & Pengambilan video proses produksi rendang dan analisis \\
\hline $12.30-13.30$ & Ishoma \\
\hline $13.30-14.30$ & Materi pendahuluan GMP, kontaminasi silang, dan higienis karyawan \\
\hline $14.30-15.45$ & $\begin{array}{l}\text { Evaluasi terhadap video proses produksi rendang yang sudah diambil dan } \\
\text { ditampilkan, serta diskusi }\end{array}$ \\
\hline $15.45-16.00$ & Penutupan \\
\hline
\end{tabular}

Metode yang digunakan dalam kegiatan ini adalah sebagai berikut:

1. Merekam proses produksi rendang di IKM Subana-bana Randang mulai dari awal, pekerja datang, melakukan persiapan produksi, melakukan produksi, dan pengemasan (dilakukan sebelum materi diberikan).

2. Memberikan materi terkait pengenalan Good Manufacturing Practices (GMP), kontaminasi silang, dan higienis karyawan dengan menggunakan video dan pemaparan langsung dari pemateri.

3. Melakukan evaluasi terkait materi yang disampaikan dengan cara meminta peserta untuk memberikan tanggapan terkait video rekaman proses produksi rendang yang sudah dilakukan sebelum materi. Partisipasi aktif dari setiap peserta menjadi keharusan untuk kesuksesan pelaksanaan kegiatan ini.

\section{HASIL DAN PEMBAHASAN}

\section{Evaluasi Kegiatan}

Metode yang digunakan dalam kegiatan ini Kegiatan Pelatihan Standar Penanganan Pangan Rendang di Sentra Produksi Randang yang diikuti oleh produsen rendang yang tergabung dalam koperasi wanita IKABOGA Padang. Peserta menunjukkan semangat yang besar dalam mengikuti setiap sesi acara dalam Pelatihan. Penyampaian materi disesuaikan dengan latar belakang peserta yang sangat beragam agar kegiatan dapat diikuti dengan baik dan tidak membosankan. Pemaparan materi terkaitan standar penanganan pangan oleh narasumber dari Jurusan Teknik 
Industri, Fakultas Teknik, Universitas Andalas berlangsung lancar dan mampu menarik minat peserta untuk ingin tahu lebih mendalam tentang penerapannya. Perekaman proses produksi rendang di IKM Subana-bana Randang dilakukan mulai dari awal, pekerja datang, melakukan persiapan produksi, melakukan produksi, dan pengemasan (dilakukan sebelum materi diberikan) dimaksudkan untuk mengetahui bagaimana produksi rendang selama ini dilakukan oleh sentra produksi rendang Padang. Setelah sesi perekaman selesai selanjutnya kepada peserta yang terlibat dalam produksi rendang diberikan materi terkait pengenalan Good Manufacturing Practices (GMP), kontaminasi silang, dan higienis karyawan dengan menggunakan video dan pemaparan langsung dari pemateri. Setelah pemaparan materi dilakukan berikutnya dilakukan evaluasi terkait materi yang disampaikan dengan cara meminta peserta untuk memberikan tanggapan terkait video rekaman proses produksi rendang yang sudah dilakukan sebelum materi. Diskusi ini bertujuan untuk membangun kemampuan dan pemahaman peserta mengenai prinsip-prinsip dan aspek-aspek yang harus diperhatikan dalam implementasi GMP. Pada saat yang sama, diskusi ini menjadi bekal bagi masing-masing peserta untuk bisa melakukan self-assessment dan menemukan titik-titik kelemahan dirinya untuk mendapatkan langkah-langkah perbaikan yang diperlukan.

\section{Assessment Penerapan GMP di Sentra Produksi Rendang}

Dari Assessment yang dilakukan bersama peserta ditemukan beberapa hal yang harus diperbaiki dalam prodses produksi rendang seperti terlihat pada Tabel 2.

Tabel 2. Hasil temuan dan penyebab permasalahan yang ada.

\begin{tabular}{|c|l|l|}
\hline No. & \multicolumn{1}{|c|}{ Temuan } & \multicolumn{1}{|c|}{ Penyebab } \\
\hline 1 & $\begin{array}{l}\text { Tata cara mencuci tangan belum sesuai } \\
\text { standar. }\end{array}$ & $\begin{array}{l}\text { Belum ada petunjuk langkah-langkah mencuci } \\
\text { tangan dan kaki. }\end{array}$ \\
\hline 2 & $\begin{array}{l}\text { Tidak terdapat ember berisi handuk } \\
\text { yang telah diberi klorin saat setelah } \\
\text { membersihkan kaki. }\end{array}$ & $\begin{array}{l}\text { Ember dengan cairan klorin belum } \\
\text { disediakan. }\end{array}$ \\
\hline 3 & $\begin{array}{l}\text { Sapu, kain pel, dan alat bersih lainnya } \\
\text { masih berada disekitar wetafel. }\end{array}$ & Penataan alat-alat belum teratur. \\
\hline 4 & $\begin{array}{l}\text { Tidak ada tempat penyimpanan } \\
\text { kebutuhan pribadi operator (loker). }\end{array}$ & Loker belum tersedia. \\
\hline 5 & $\begin{array}{l}\text { Sabun untuk membersihkan peralatan } \\
\text { masak masih berada diarea pencucian } \\
\text { bahan mentah untuk memasak. }\end{array}$ & Penataan alat-alat belum teratur. \\
\hline 6 & $\begin{array}{l}\text { Peralatan untuk memasak (masker, } \\
\text { clemek, tutup kepala, sarung tangan) } \\
\text { tidak pada tempatnya. }\end{array}$ & Penataan alat-alat belum teratur. \\
\hline 7 & $\begin{array}{l}\text { Tidak ada SOP untuk mencuci tangan } \\
\text { dan penggunaan peralatan untuk } \\
\text { memasak. }\end{array}$ & $\begin{array}{l}\text { SOP untuk mencuci tangan belum ada dan } \\
\text { SOP untuk menggunakan peralatan memasak. }\end{array}$ \\
\hline 8 & $\begin{array}{l}\text { Saat mencuci bahan mentah (daging, } \\
\text { sayur, dll) tidak menggunakan air } \\
\text { mengalir dan tidak menggunakan } \\
\text { sarung tangan. }\end{array}$ & Belum ada SoP cara mencuci bahan. \\
\hline 9 & $\begin{array}{l}\text { Alur kerja masih bolak-balik. } \\
\text { Terdapat alat-alat yang tidak digunakan }\end{array}$ & Penataan alat-alat belum teratur. \\
\hline & $\begin{array}{l}\text { Tidak menggunakan rak troli. } \\
\text { untuk memasak pada meja. }\end{array}$ & \\
\hline
\end{tabular}


Sambungan Tabel 2. Hasil temuan dan penyebab permasalahan yang ada.

\begin{tabular}{|l|l|l|}
\hline 11 & $\begin{array}{l}\text { Alat dan sabun untuk pembersih } \\
\text { ruangan berada pada rak peralatan } \\
\text { memasak. }\end{array}$ & $\begin{array}{l}\text { Penataan alat-alat belum teratur, warning } \\
\text { atau simbol pada peralatan masak belum ada. }\end{array}$ \\
\hline 12 & $\begin{array}{l}\text { Letak alat pemadam api di lantai dengan } \\
\text { kipas angin. }\end{array}$ & Penataan alat-alat belum teratur. \\
\hline 13 & $\begin{array}{l}\text { Menggunakan kipas angin pada area } \\
\text { produksi. }\end{array}$ & Sirkulasi udara tidak bagus. \\
\hline
\end{tabular}

Berdasarkan hasil Tabel 2 di atas, maka kami dari tim pelatihan merekomendasikan untuk menyesuaikan kembali standar kerja dengan Standar Penanganan Pangan yang baik yang mengacu pada Good Manufacturing Practices (GMP).

\section{KESIMPULAN}

Dari kegiatan Pelatihan Standar Penanganan Pangan Rendang di Sentra Produksi Randang yang telah dilaksanakan dapat ditarik beberapa kesimpulan sebagai berikut: 1). Peserta Pelatihan memahami pentingnya pemenuhan standar keamanan pangan tidak hanya bagi konsumennya, namun juga bagi keberlangsungan usaha IKM. 2). Masing-masing peserta telah mendapatkan pemahaman umum tentang standar penanganan pangan yang baik karena peserta telah melakukan self-assessment tentang seberapa baik penerapan GMP. 3). Hasil assessment penerapan standar penanganan pangan menunjukkan bahwa masih ada perbaikan yang harus dilakukan. Untuk perbaikan di masa yang akan dating, maka beberapa saran yang dapat diajukan meliputi: 1). Diusulkan adanya kegiatan pendampingan yang dilaksanakan berbagai instansi terkait dengan bekerja sama dengan perguruan tinggi untuk penjaminan kualitas pangan olahan dalam rangka penguatan IKM. 2). Produsen rendang yang sudah lebih siap didorong untuk melakukan pendaftaran usahanya ke Badan POM dan sertifikasi Halal dari LPPOM MUI sebagai bagian dari usaha penguatan pemasaran IKM.

\section{UCAPAN TERIMA KASIH}

Terimakasih kepada seluruh pihak yang telah terlibat kegiatan ini. Ucapan terima kasih juga disampaikan kepada Jurusan Teknik Industri Universitas Andalas telah memberikan dana pengabdian ini dengan anggaran dana tahun 2019.

\section{DAFTAR PUSTAKA}

Adinegoro, H. (2016). Strategi Peningkatan Mutu Keamanan Produk Bakeri Industri Kecil Menengah Melalui Penerapan Good Manufacturing Practices (GMP): The Strategy of Improving Food Safety Base on Implementation Good Manufacturing Practises (GMP'S) On Small-Medium Enterprises Bakery. Majalah Ilmiah Pengkajian Industri. https://doi.org/10.29122/mipi.v10i1.98

Rudiyanto, H. (2016). Kajian Good Manufacturing Practices (GMP) dan Kualitas Mutu pada Wingko Berdasarkan SNI-01-4311-1996. Jurnal Kesehatan Lingkungan.

Yudhastuti, R. (2014). Penerapan Good Manufactoring Practices pada Industri Rumah Tangga Kerupuk Teripang di Sukolilo Surabaya. Jurnal Kesehatan Lingkungan. 